\title{
Adaptation to Long-Term Rainfall Variability for Robusta Coffee Cultivation in Brazilian Southeast
}

\author{
Lima Deleon Martins',2, Fernando Coelho Eugenio ${ }^{2,3}$, Wagner Nunes Rodrigues', \\ Sebastião Vinicius Batista Brinati ${ }^{1}$, Tafarel Victor Colodetti ${ }^{1}$, Bruno Fardim Christo', \\ Dionicio Belisario Luis Olivas',4, Fábio Luiz Partelli1,5, José Francisco Teixeira do Amaral ${ }^{1}$, \\ Marcelo Antonio Tomaz ${ }^{1,2}$, José Domingos Cochicho Ramalho', Alexandre Rosa dos Santos ${ }^{1,2}$ \\ ${ }^{1}$ Center of Agrarian Sciences and Engineering, Federal University of Espirito Santo-CCAE/UFES, Alegre, Brazil \\ ${ }^{2}$ Geotechnology Applied to Global Environment-CNPq Advanced Research Group-GAGEN, Alegre, Brazil \\ ${ }^{3}$ Federal University of Santa Maria, Santa Maria, Brazil \\ ${ }^{4}$ José Faustino Sánchez Carrión National University, Huacho, Peru \\ ${ }^{5}$ North University Center, Federal University of Espirito Santo-CUNES/UFES, São Mateus, Brazil \\ ${ }^{6}$ Plant-Environment Interactions \& Biodiversity Lab (Plant Stress \& Biodiversity), Linking Landscape, Environment, Agriculture \\ and Food, (LEAF), Dept. Recursos Naturais, Ambiente e Territorio (DRAT), Instituto Superior de Agronomia (ISA), \\ Universidade de Lisboa (ULisboa), Quinta do Marques, Oeiras, Portugal \\ Email: limadeleon@gmail.com
}

How to cite this paper: Martins, L.D., Eugenio, F.C., Rodrigues, W.N., Brinati, S.V.B., Colodetti, T.V., Christo, B.F., Olivas, D.B.L., Partelli, F.L., do Amaral, J.F.T., Tomaz, M.A., Ramalho, J.D.C. and dos Santos, A.R. (2018) Adaptation to Long-Term Rainfall Variability for Robusta Coffee Cultivation in Brazilian Southeast. American Journal of Climate Change, 7, 487-504.

https://doi.org/10.4236/ajcc.2018.74030

Received: August 10, 2018

Accepted: September 27, 2018

Published: September 30, 2018

Copyright (c) 2018 by authors and Scientific Research Publishing Inc. This work is licensed under the Creative Commons Attribution International License (CC BY 4.0).

http://creativecommons.org/licenses/by/4.0/

c) (i) Open Access

\begin{abstract}
Coffee is one of the world most traded agricultural commodities. Currently, a lot of attention has been on Robusta coffee (Coffea canephora Pierre ex A. Froehner) because it seems to evidence a greater tolerance to extreme climatic events than Arabica coffee ( $C$. arabica L.). Despite this, only a few works have been developed aimed at discriminating the climatic vulnerability in regions which prioritize robust coffee production. The aim of this work was to analyze historical climatic variables in space and time for the characterization of climatic vulnerability of micro-regions, in search of mitigation and adaptation, which might support the improvement of production systems of $C$. $\mathrm{Ca}$ nephora coffee trees. The case study was carried out for one of the largest production regions of Robusta coffee of the world, in Brazil, geographically located between the $39^{\circ} 38^{\prime}$ and $41^{\circ} 50^{\prime}$ West longitude meridians and the $17^{\circ} 52^{\prime}$ and $21^{\circ} 19^{\prime}$ South latitude parallels. The vulnerability was characterized by the spatial and temporal variation of rainfall and rainfall seasonal pattern (based on 30 years of historical data), elements of climatic water balance, elevation and area planted with Robusta coffee. The choice of mitigation and adaptation were based on widely validated criteria. Overall, the results show that the vulnerability of Robusta coffee is related to low index of rainfall, the
\end{abstract}


rainfall seasonability and the water deficiency. In the studied region, there is approximately $42 \%$ of some type of water vulnerability during the year, with a severe to medium scale; this vulnerability is very pronounced in regions farther away from the coast of the Atlantic Ocean, since for a year approximately $92 \%$ of them are water deficient. In addition, the data show that this distance from the ocean implies a reduction of $75 \%$ in the phases of water surplus not only. The strategies of greater potential for adaptation and mitigation are related to the planting of improved genotypes, utilization of polycultures systems, increasing plant density, the implementation of irrigation systems and the management of spontaneous plants.

\section{Keywords}

Coffea canephora, Rainfall, Climate Change, Shade, Irrigation

\section{Introduction}

Coffee beans are undoubtedly important as a source of wealth for the countries of Latin America, Asia and Africa, representing the second largest commodity in economic value for trade [1]. The cultivation of coffee is widespread in tropical and equatorial regions where the occurrence of droughts, in particular, are even more harmful due to its association with high irradiance and temperature, which affect the agroecosystem and generate a complex stress that can limit several physiological processes of the coffee plants [2].

Drought is a climatic phenomenon that occurs due to insufficient precipitation in a region; its occurrence leads to water stress in plants, which is a multidimensional phenomenon and is related not only to the insufficiency of water in the soil, but also in the atmosphere [3]. Some species, and even some genotypes within the same species, may develop different levels of susceptibility to water stress caused by drought. As Coffea canephora Pierre ex A. Froehneris originated from regions with abundant and well-distributed rainfall, throughout the evolutionary process, this species developed itself as a water expender tree [2].

Advanced studies that seek to understand the impacts of climate change in coffee plants-such as rising $\mathrm{CO}_{2}$ concentration and average air temperature, reduction of soil water supply and even soil water deprivation-have pointed to effective metabolic and genetic adjustments as a way of mitigating the negative implications of climatic change [2] [4]-[9]; in particular to the water deficit, some results indicate that coffee plants acquire tolerance due to photosynthetic and metabolic acclimatization to repeated drought events [10] that can be strongly governed by transcriptional memory [11].

Even recently improved and highly productive cultivars are formed with genotypes that usually still present high hydric demand and are vulnerable to the occurrence of periods of drought [12], which denotes the need for adaptation strategies to attenuate the effects of climate change focused on microregions, 
given the variability of metabolic and genetic implications often presented by coffee plants [2].

One of the main target regions for studies involving Robusta coffee is the Espírito Santo State (Southeast Region of Brazil), which, although it occupies less than $0.5 \%$ of the Brazilian territory, has one of the most imposing coffee productions and also develops one of the main breeding programs of the species worldwide [12]. The main coffee producing regions in the Espírito Santo State present soils with low water retention capacity and great irregularity in pluvial precipitation, with recent periods of prolonged drought being frequent [13].

Altogether, consistent data on climate vulnerability have been found in regions above equator, primarily for the cultivation of Arabica coffee or growing both (Arabica and Robusta coffees), aiming to identify adaptation strategies or to simulate future climate impacts. But the literature presents few or no studies that address similar themes for regions where Robusta coffee is cultivated below equator. The objectives of this study were: 1) to analyze historical climatic variables in a spatial and temporal way with a focus on possible water impacts; 2) to characterize the hydro-climatic vulnerability of microregions; 3 ) in the search for adaptation strategies that may support the improvement of systems to maintain the sustainability of cultivation of Robusta coffee trees.

\section{Materials and Methods}

\subsection{Crop Area of Coffea canephora}

The Coffea canephora plantations (season 2012/2013) covers approximately $42 \%$ $(127.888 \mathrm{ha}$ ) of the planted area in the northeast region (Figure 1), with the municipality of Vila Valério (coordinates $18^{\circ} 59^{\prime} \mathrm{S}, 40^{\circ} 23^{\prime} \mathrm{W}, 238 \mathrm{~m}$ of elevation) representing the world greatest producer of Robusta coffee, with a production of 44,550 Tons of green beans with a value of ca. US\$ 73,798 million [14]. The northern region has the second greatest area planted, representing ca. 37\% $(111,030 \mathrm{ha})$, with special mention for the municipality of Jaguaré (coordinates $18^{\circ} 4^{\prime} \mathrm{S}, 40^{\circ} 04^{\prime} \mathrm{W}, 70 \mathrm{~m}$ of elevation) which has approximately 19,000 ha. The central region $(38,974 \mathrm{ha})$ and South $(25,174 \mathrm{ha})$ have smaller production areas, representing $13 \%$ and $8 \%$ of the area planted, respectively (Figure 1).

\subsection{Case Study and Climatic Data}

The study was performed considering the State of Espírito Santo $\left(46,184.1 \mathrm{~km}^{2}\right)$, located between the meridians $39^{\circ} 38^{\prime}$ and $41^{\circ} 50^{\prime}$ of West longitude and the parallels $17^{\circ} 52^{\prime}$ and $21^{\circ} 19^{\prime}$ of South latitude (Figure 2). The geographic stratification of the area planted with Robusta coffee (ha) was carried out based on the agriculture and cattle raising characterization of the 2012/2013 census [14].

Climate data was obtained from monthly air temperature and rainfall series (1983-2013) collected from 94 measuring points, from the meteorological stations of InstitutoCapixaba de Pesquisas e Extensão Rural, INCAPER (11), of the 


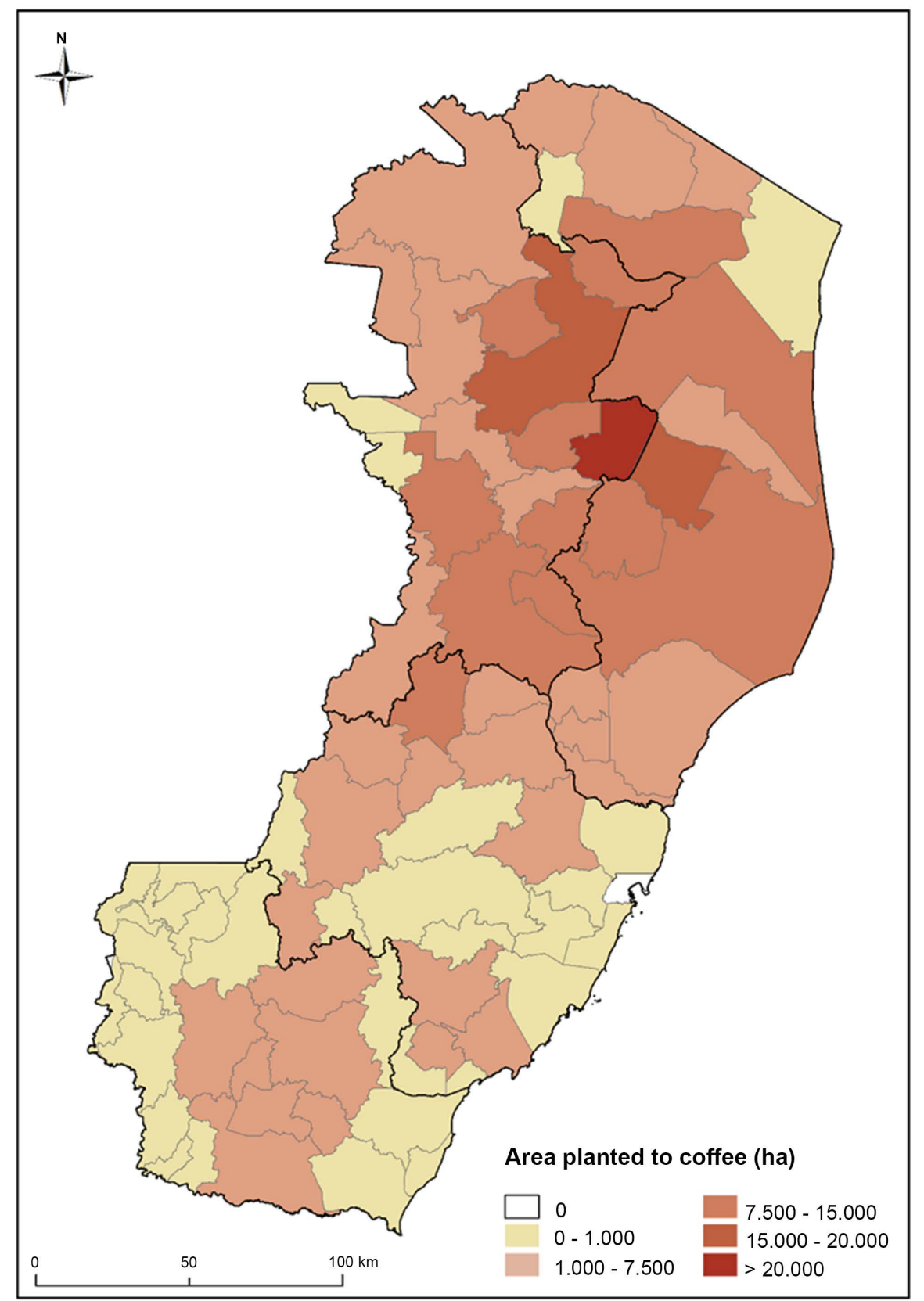

Figure 1. Stratification of the area cultivated with Coffea canephora (crop season $2012 / 2013$ ) based on the agricultural census 2012/2013 [14], geographically located between the meridians $39^{\circ} 38^{\prime} \mathrm{W}$ and $41^{\circ} 50^{\prime} \mathrm{W}$ of longitude and the parallels $17^{\circ} 52^{\prime} \mathrm{S}$ and $21^{\circ} 19^{\prime} \mathrm{S}$ of latitude. The predictive values for each region (South, Central, Northwest and North) are represented by color (see legend internal).

Instituto Nacional de Meteorologia, INMET (3) and of the Agência Nacional de Águas, ANA (80). To minimize the edge/border effect in the interpolation process, there were included 16 additional rainfall measuring stations (ANA), located outside the area of study, with the objective of favoring interpolation statistics. All operations were based on points located in the State of Espírito Santo and bordering areas. 


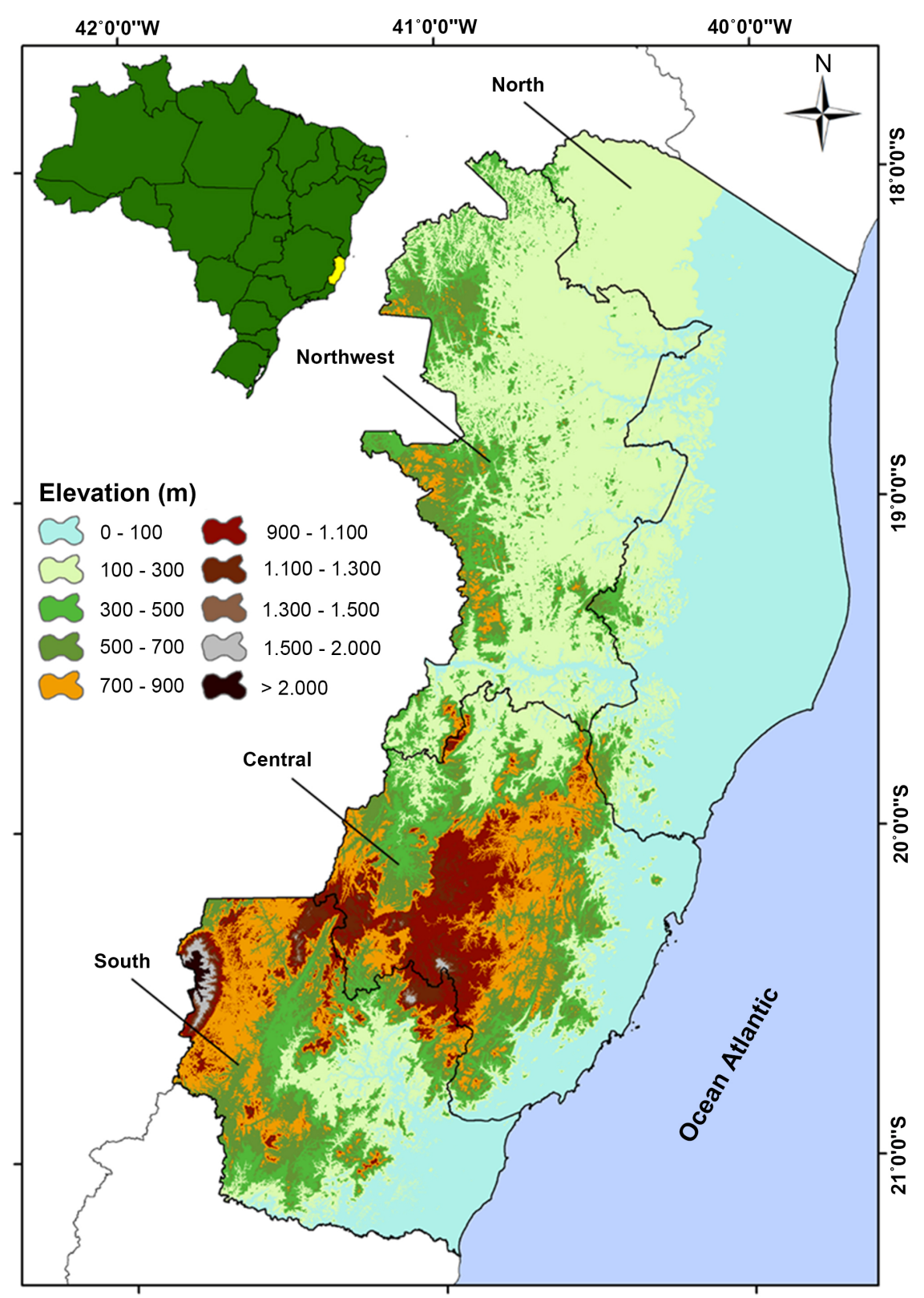

Figure 2. Geographical location, description and altitude of the study area $\left(46,184.1 \mathrm{~km}^{2}\right)$ is located in Southeast Region of Brazil, being limited by the Atlantic Ocean to east, the State of Bahia to north, the State of Minas Gerais to west and the State of Rio de Janeiro to south; between the meridians $39^{\circ} 38^{\prime} \mathrm{W}$ and $41^{\circ} 50^{\prime} \mathrm{W}$ of longitude and the parallels $17^{\circ} 52^{\prime} \mathrm{S}$ and $21^{\circ} 19^{\prime} \mathrm{S}$ of latitude. The average altitude was obtained using a digital elevation model $(90 \times 90$ meters; scale 1:250,000 and map projection WGS84) obtained by the project Shuttle Radar Topography Mission-SRTM [15], ranging from zero meters (sea level) to approximately 2,800 meters (southwest) (see legend internal).

\subsection{Spatialization of the Rainfall}

The spatialization of mean monthly rainfall was carried out though the geostatistics technique of spatial interpolation by kriging, using spherical (January, February, March and August), linear (April, May, June, July, September, November 
and December) and exponential (October) models according to an adequate statistical adjustment [16] [17].

\subsection{Climatic Water Balance and Rainfall Seasonability}

The climatic water balance was studied for each region (South, Central, Northeast and North) based on climate data of mean air temperature, mean rainfall and mean latitude, adopting the available water capacity at $100 \mathrm{~mm}$ [18]. The rainfall seasonality was obtained for the same regions based on the rainfall data (mean, 25 and 75 percentiles, maximum and minimum) and expressed using a box plot model [19]. The spatialization of annual water deficiency and potential evapotranspiration was carried out through a geostatistical technique of spatial interpolation by kriging, using exponential and spherical models, respectively [20].

\subsection{Vulnerability Characterization and Strategies of Adaptation}

The vulnerability was characterized in accordance to the water (annual water deficiency) aptitude categories for the cultivation of Robusta coffee. It was considered as adequate the conditions with water deficit (DHa) below $200 \mathrm{~mm}$. Conditions with DHa higher than $200 \mathrm{~mm}$ were considered as limiting.

The practices to mitigate and adapt the cultivation (climate smart agricultural), based on widely accepted and validated criteria [21]-[27] were chosen based on its potential to 1) mitigate negative climate impacts 2) contribute to the adaptation of future climate scenarios, 3) increase sequestration of carbon or reduce the carbon footprint of the coffee production system and 4) the contribution in accordance to the vulnerability evaluation. Furthermore, such mitigation and adaptation activities must offer benefits for local subsistence, with local social and economic benefits.

\subsection{Analyze of Data}

The utilization of the geostatistical models of spatial interpolation were based on the coefficient of determination of crossed validation $\left(\mathrm{R}^{2}\right)$, at the root of the quadratic mean error (RMSE), in the index of agreement (D), in the index of confidence $\odot$, in the coefficient of adjustment (E'), in the absolute mean (EMA) and the percentage mean error (EMP-\%) [16] [17], for:

$$
\begin{gathered}
\text { RMSE }=\sqrt{\frac{1}{n} \sum_{i=1}^{n}\left(Y_{i}-O_{i}\right)^{2}} \\
d=1-\frac{\sum_{i=1}^{J}\left(O_{i}-E_{i}\right)^{2}}{\sum_{i=1}^{J}\left(\left|E_{i}-B\right|_{+}\left|O_{i}-B\right|\right)^{2}} \\
E^{\prime}=1-\frac{\sum_{i=1}^{J}\left|O_{i}-E_{i}\right|}{\sum_{i=1}^{J}\left|O_{i}-B\right|} \\
E M A=\frac{\sum_{i=1}^{J}\left|O_{i}-E_{i}\right|}{J}
\end{gathered}
$$




$$
\operatorname{EMP}(\%)=\frac{\sum_{i=1}^{J} \frac{\left|O_{i}-E_{i}\right|}{O_{i}}}{J} * 100
$$

where, number of observations ( $)$; value observed experimentally $(O)$; estimated value by method $(E)$; mean of experimentally observed values $(B)$; value i of the climatic variable simulated by the model (y); number of observed and simulated data partner $(n)$. For index of confidence (c): optimal $(>0.85)$; very good $(0.76$ to 0.85 ); good (0.66 to 0.75$)$; median (0.61 to 0.65$)$; ( 0.51 to 0.60$)$; poor (0.41 to $0.50)$ and very poor $(\leq 0.40)$.

All spacializations were performed with the program ArcGIS ${ }^{\circledR}$ (version 10.2, $\mathrm{ESRI}^{\mathrm{TM}}$ ). The climate data to study the climatic water balance and its stratification, as well as the rainfall seasonality were grouped for the regions (South, Center, Northeast and North) and statistically analyzed for the normal verification (Kolmogorov-Smirnov, level of significance of 0.05) through the Genes program [28]. Some rainfall data absence were overcome with estimate using regional ponderation values referred to the three closer points [20] [29].

\section{Results and Discussion}

\subsection{Variation in Rainfall Distribution}

As expected, rainfall values distributed unevenly throughout the year, with high values (from 125 up to higher than $275 \mathrm{~mm}$ ) found between November and March (excepting February) and low values $(<75 \mathrm{~mm})$ between May and September. April and September are transition periods, which are common in tropical areas (Figure 3). Concerning the spatial distribution amongst the several areas, there is a tendency to relate the periods of low rainfall values to lower elevation, and on the contrary, periods of high rainfall in areas of higher elevation (Figure 3). This fact can be explained, at least in part, by the influence of the meteorological phenomenon called the South Atlantic Convergence Zone.

\subsection{Climatic Water Balance and Evapotranspiration}

The annual water deficit balance (Figure 4) revealed that most of the South, Central and Northern region has a predominance of areas with less than 200 $\mathrm{mm}$ of water deficit. For the Central and South that seemed to be partly justified, due to the interaction of greater elevations (Figure 2), higher rainfall values and lower mean air temperature [4]. In the Northeast region and the upper part of the North region, the water deficiency showed annual values between 200-400 $\mathrm{mm}$, due to the influence of elevated mean air temperatures and moderate rainfall values [4]. In addition, there are areas in the lower segment of the Northeast region and near the sea in the southern region with a water deficiency above 400 $\mathrm{mm}$ annually, a fact which suggests a process of desertification in progress, having the climate vulnerability, as well as the soil type and topography as mitigating factors [30].

The annual evapotranspiration (Figure 5) points out that values lower than 

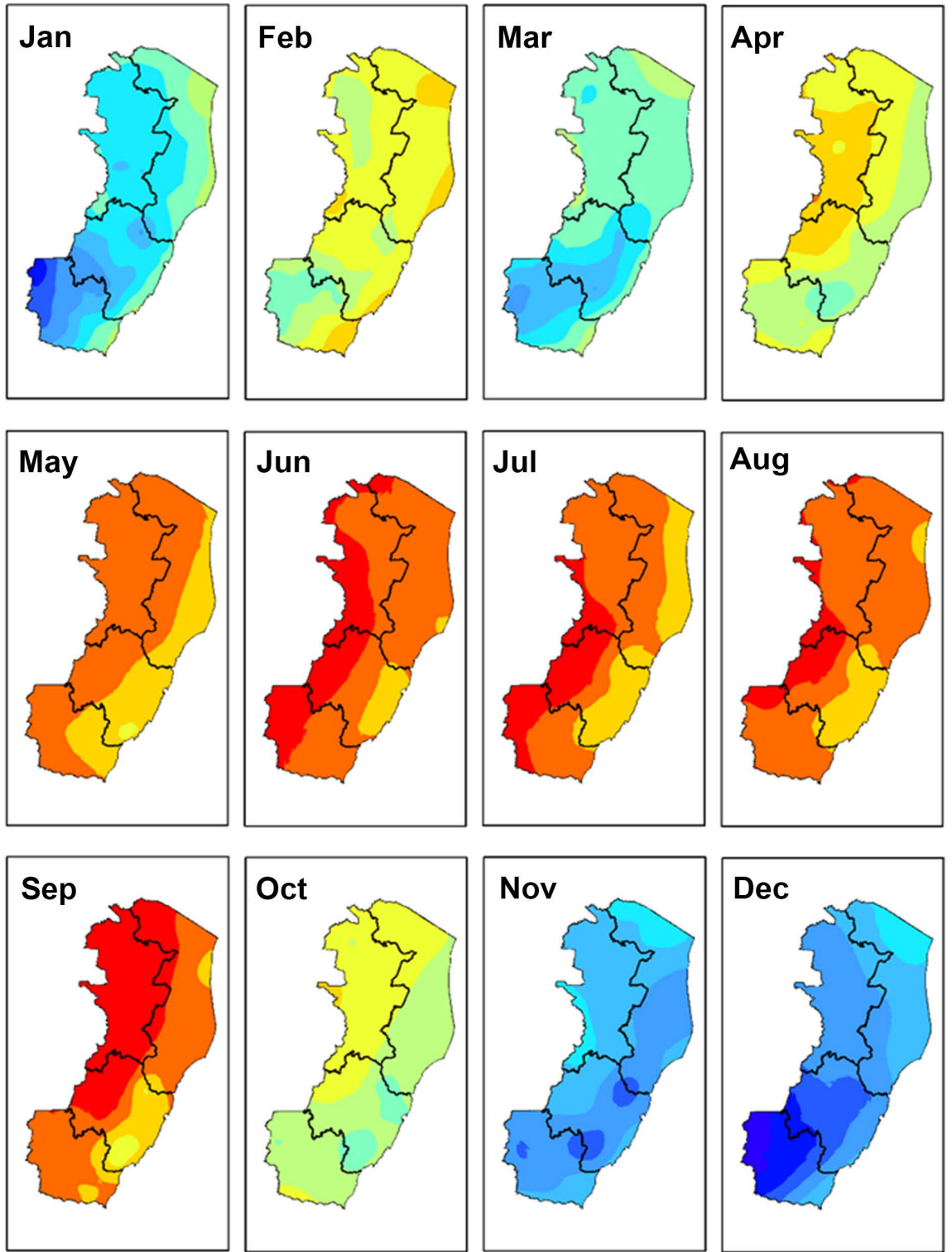

Monthly means of rainfall $(\mathrm{mm})$
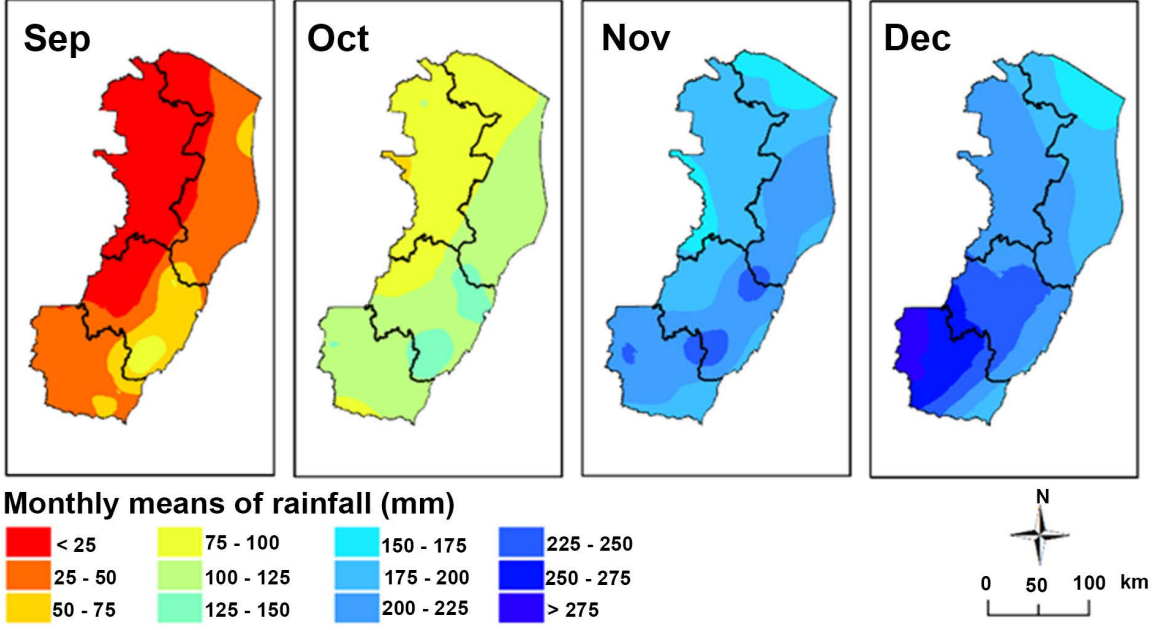

Figure 3. Geographical distribution of the monthly means of rainfall (mm). Monthly variation (January to December) of the rainfall, obtained with spatial interpolation (90 pixel $\times 90 \mathrm{~m}$ ) by Kriging, using spherical model (January, February, March and August), linear (April, May, June, July, September, November and December) and exponential (October) fitted to semivariogram (nugget, range and sill effects) [16] [17], based on historical weather data (1983-2013). The predictive values for each region (South, Central, Northwest and North) are represented by color (see legend internal), with low values marked in deep blue $(<25 \mathrm{~mm})$ and high values in red $(>275 \mathrm{~mm}$ ) (see the main text for details).

$900 \mathrm{~mm}$ are related to greater altitude areas (Figure 2) with a low mean air temperature [4], following a general tendency of the reduction of values from the East (e.g., $1.200-1.300 \mathrm{~mm}$ ), near the coast, to West (e.g., $900-1.100 \mathrm{~mm}$ ). 


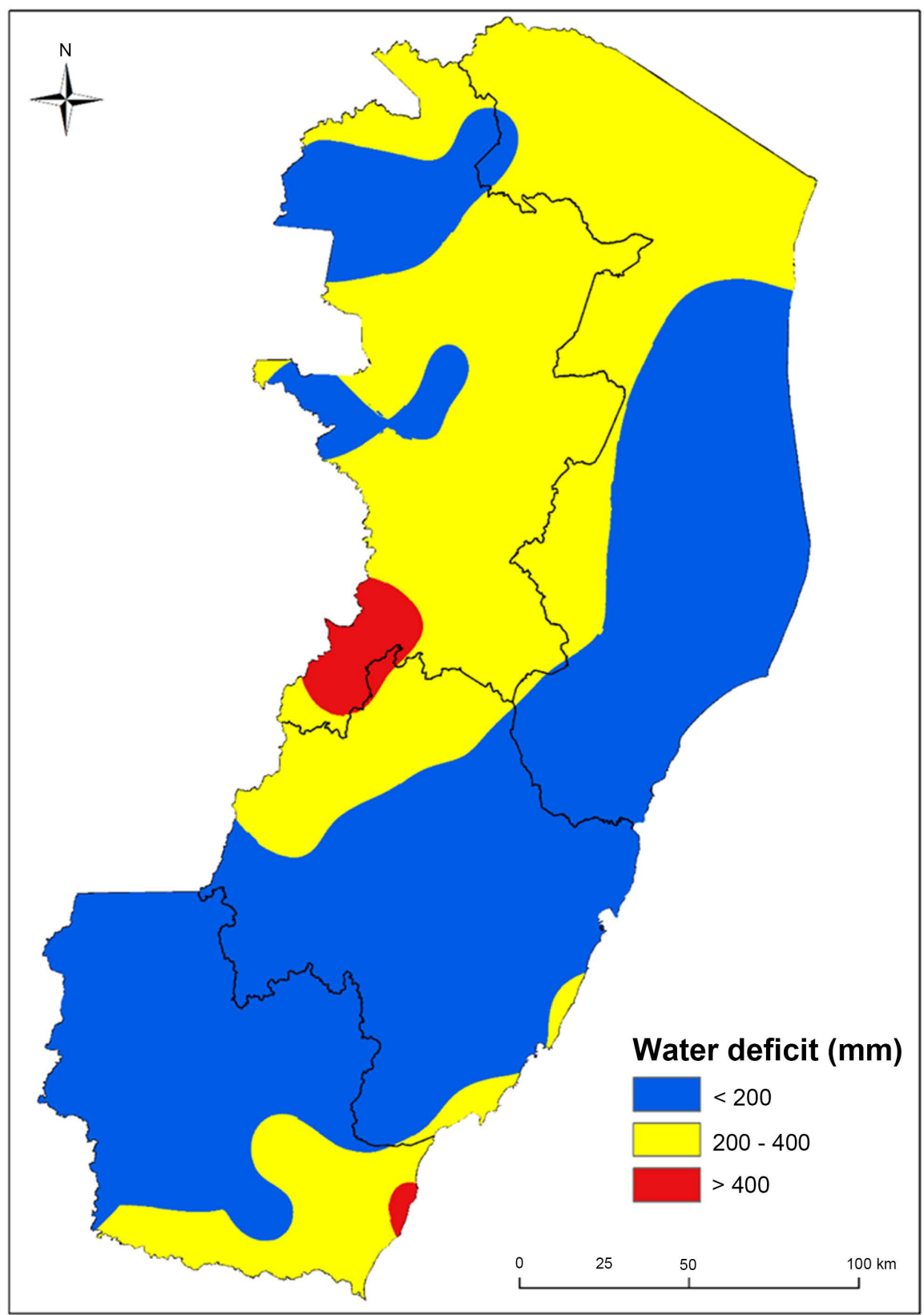

Figure 4. Geographical distribution of the annual means of water deficit (mm). Annual variation of water deficit, obtained with spatial interpolation (pixel $90 \times 90 \mathrm{~m}$ ) by Kriging, using exponential model fitted to semivariogram (nugget, range and sill effects) [20], based on historical weather data (1983-2013). The predictive values [31] for each region (South, Central, Northwest and North) are represented by color (see legend internal), with low values marked in blue $(<200 \mathrm{~mm})$, average values in yellow $(200-400 \mathrm{~mm})$ and high values in red $(>400 \mathrm{~mm})$ (see the main text for details).

That shows the relevant function of topography, longitude and influence of ocean proximity [32].

The water balance for the years 1983-2013 shows that the southern (Figure 6(a)) and the central regions (Figure 6(b)) presented an historical occurrence of low annual water deficit, respectively, of $70.20 \mathrm{~mm}$ and $13.26 \mathrm{~mm}$ during the 


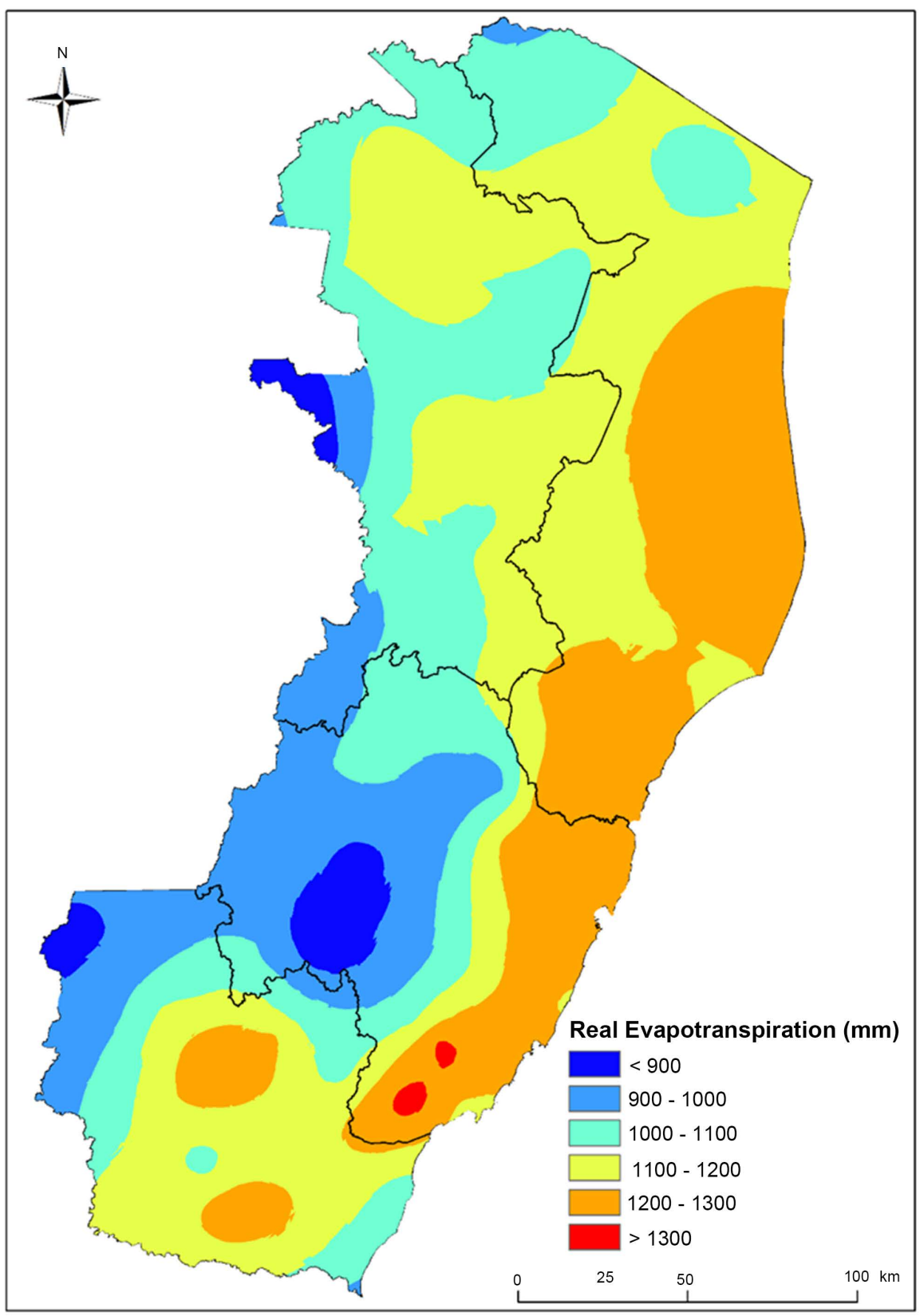

Figure 5. Geographical distribution of the annual means of real evapotranspiration $(\mathrm{mm})$. Annual variation of real evapotranspiration [33], obtained with spatial interpolation (pixel $90 \times 90 \mathrm{~m}$ ) by Kriging, using exponential model fitted to semivariogram (nugget, range and sill effects) [20], based on historical weather data (1983-2013). The predictive values [21] for each region (South, Central, Northwest and North) are represented by color (see internal label), with low values marked in deep blue $(<900 \mathrm{~mm})$ and high values in red $(>1300 \mathrm{~mm})$ (see the main text for details).

months of May and September. On the other hand, between October and April (except February) was found a positive water balance of 251.41 and $339.21 \mathrm{~mm}$ for these areas, respectively (Figure 6(a) and Figure 6(b)). For the North (Figure 6(c)) and Northeast (Figure 6(d)) regions, the analyzed period presented strong annual water deficits, of 297.71 and $315.07 \mathrm{~mm}$, respectively, from 


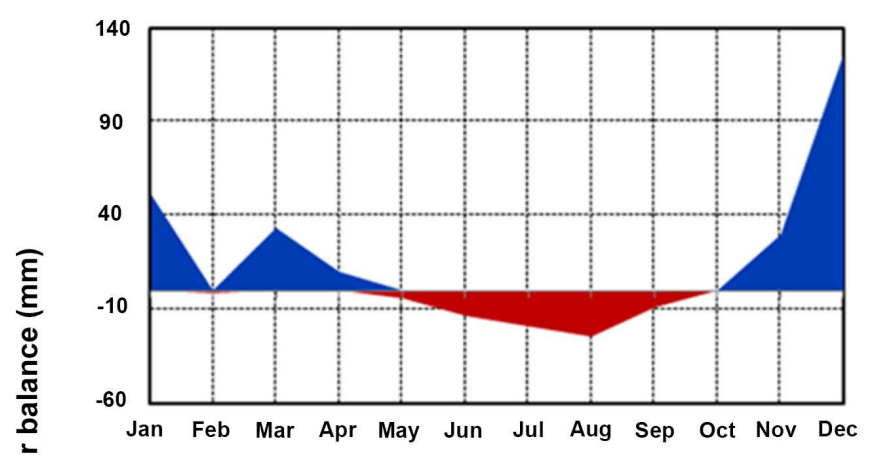

(a)

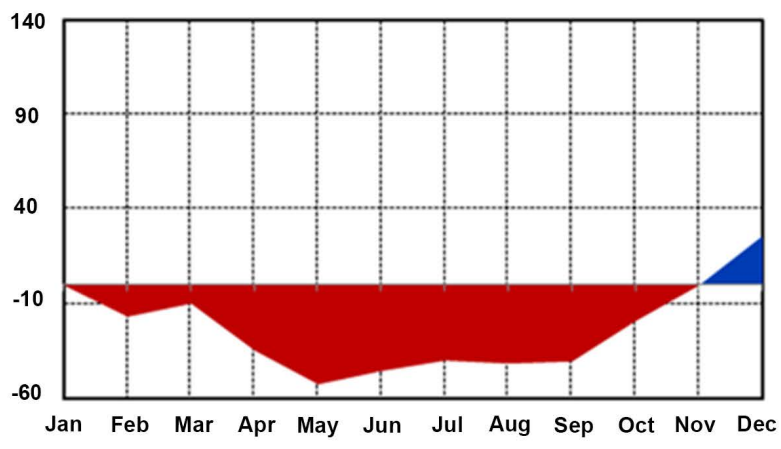

(c)

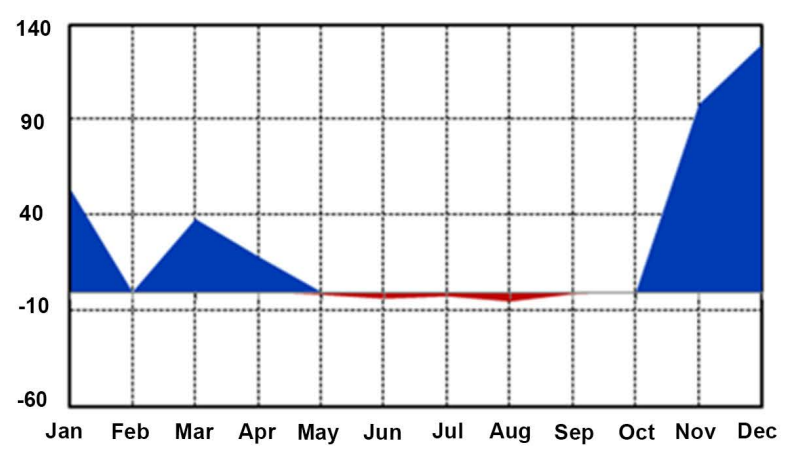

(b)

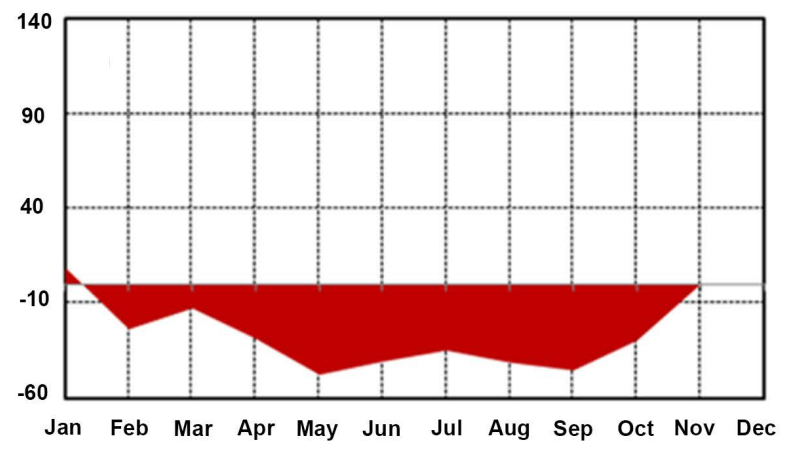

(d)

Figure 6. Climatic water balance $(\mathrm{mm})$. Graphic representation of the monthly (January to December) historical mean values (1983-2013) of water surplus (blue) and water deficiency (red) for the regions: South (a), Central (b), North (c) and Northwest (d), obtained by weather data of mean air temperature, mean rainfall and mean latitude, adopting the available water capacity of 100 $\mathrm{mm}$ [18]. Significant by the Kolmogorov-Smirnov test ( $\mathrm{p}$ value $<0.05$ ).

January to October, whereas a low positive water balance $(25.66 \mathrm{~mm})$ was found only for the North region, between November and December (Figure 6(c)).

A finer analysis for the water balance showed that the stock for withdrawal (rose area) of water from the soil in the South, North and Northeast regions are similar, with values of $92.32 \mathrm{~mm}, 98.02 \mathrm{~mm}$ and $98.26 \mathrm{~mm}$, respectively (Figure $7(\mathrm{a})$, Figure 7 (c) and Figure $7(\mathrm{~d})$ ). The evidence of a high hydric deficiency in the north and northeast regions (Figure 4, Figure 6(c) and Figure 6(d); Figure $7(\mathrm{c})$ and Figure $7(\mathrm{~d})$ ) seemed to be related to the high indexes of real evapotranspiration (Figure 5), high air temperatures [4] and low rainfall values between September and May (Figure 3, Figure 8(c) and Figure 8(d)).

The water deficiency impact can be exacerbated by the rainfall distribution along the year (that is, its seasonality) shown in all studied regions (Figure 8). The results from this period (1983-2013) clearly showed that the highest rainfall values occur mostly in the months of higher air temperatures (except for the month of February which typically shows smaller rainfall values), and a strong seasonality in the transition periods (April and September) (Figure 8), which may increase the water deficiency and the vulnerability of cultivation of Robusta coffee trees. 


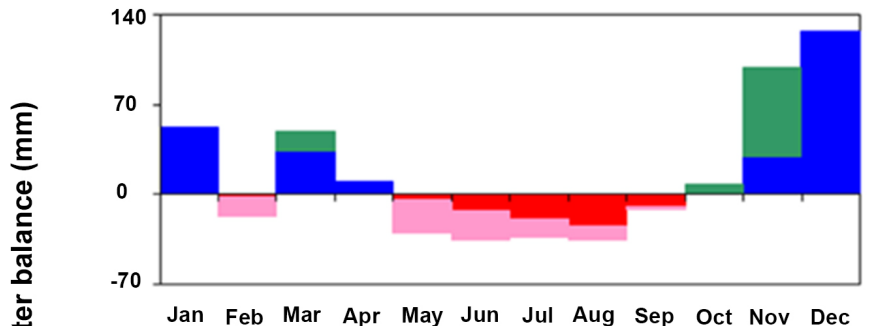

(a)

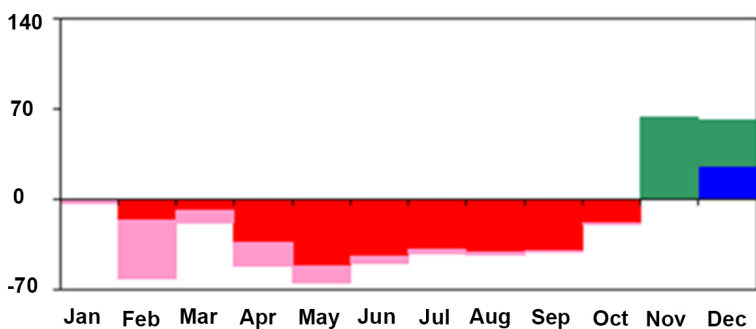

(c)

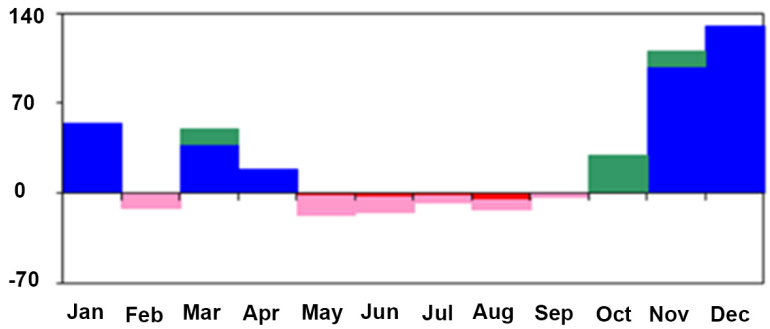

(b)

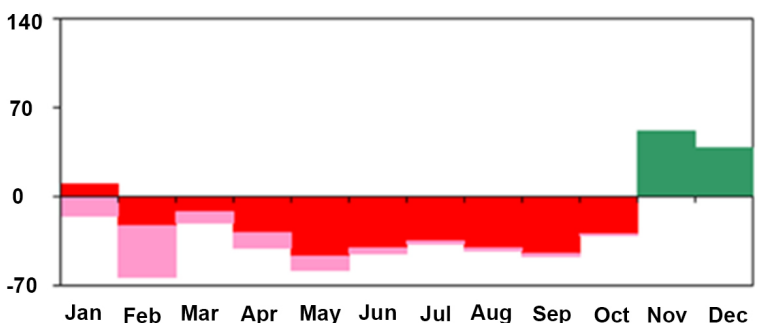

(d)

Hydro withdrawal

Water deficiency

Figure 7. Stratification of the climatic water balance $(\mathrm{mm})$. Monthly histogram (January to December) of historical mean values (1983-2013) of water surplus (blue), reposition (green), withdrawal (pink) and water deficiency (red) for the regions: South (a), Central (b), North (c) and Northwest (d), obtained by weather data of mean air temperature, mean rainfall and mean latitude, adopting the available water capacity of $100 \mathrm{~mm}$ [18]. Significant by the Kolmogorov-Smirnov test ( $\mathrm{p}$ value $<0.05$ ).

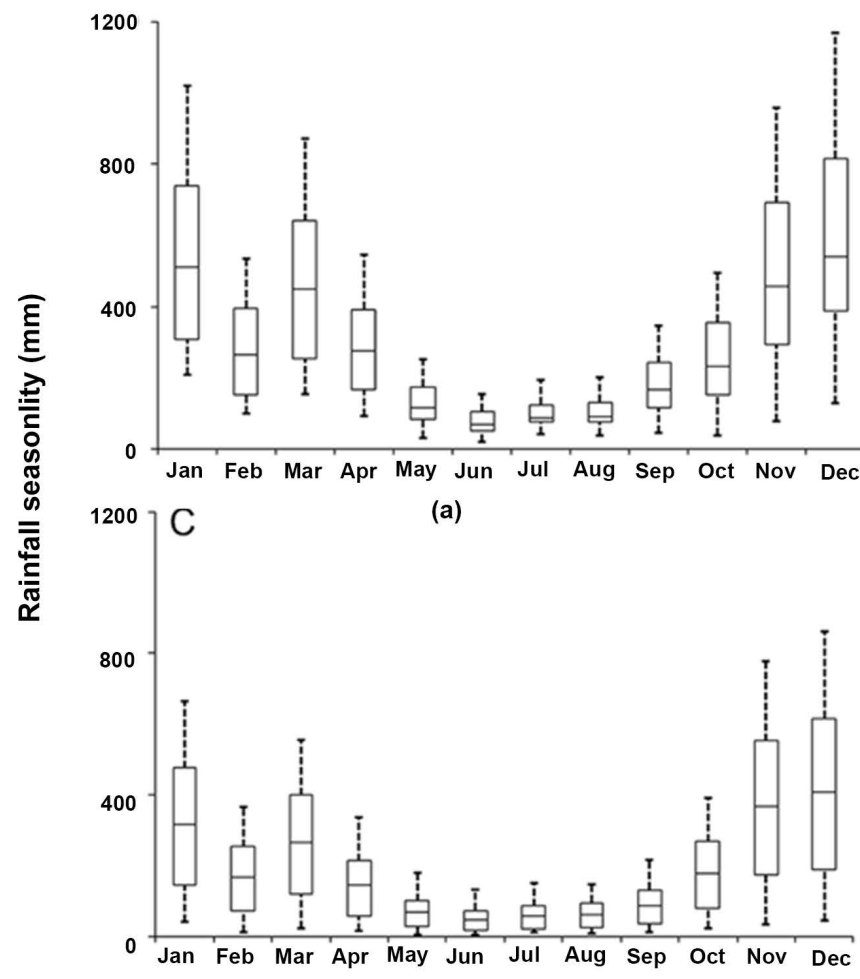

(c)

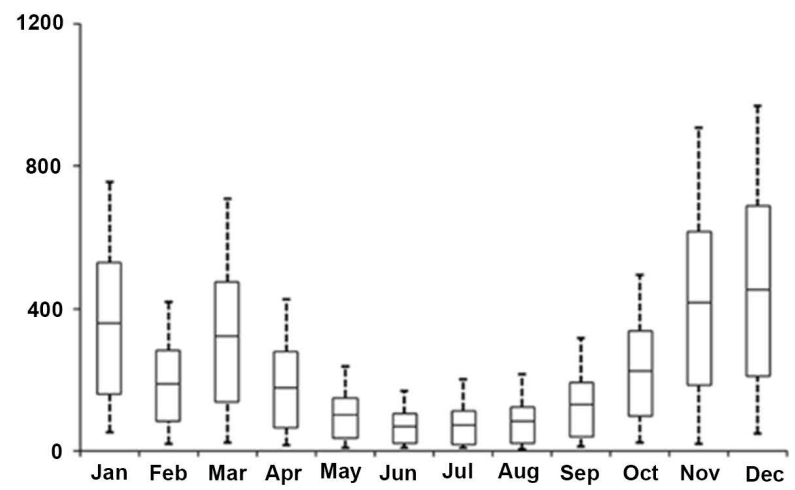

(b)

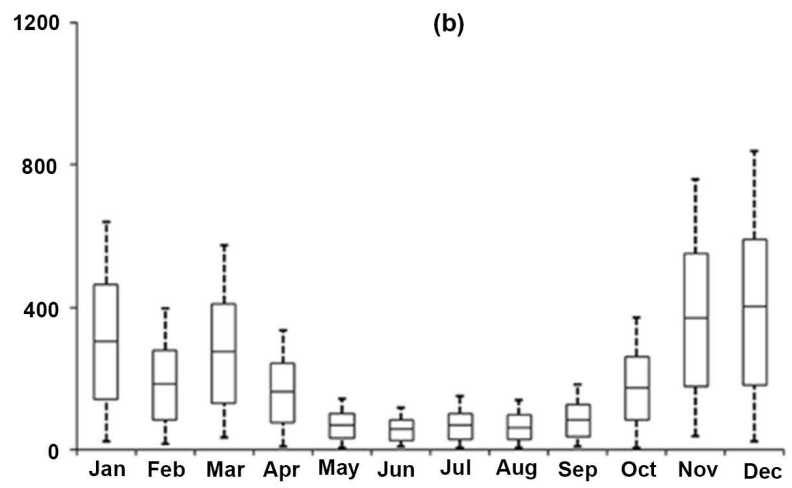

(d)

Figure 8.Rainfall seasonality (mm). Dispersion of historical weather data (1983-2013) of rainfall for the regions: South (a), Central (b), North (c) and Northwest (d). The horizontal line in each box indicates the median; the upper and lower limits show respectively the values of percentiles 75 and 25; maximum and minimum values are indicated by the symbols of horizontal support at the ends of dotted lines in each boxplot. Significant by the Kolmogorov-Smirnov test ( $p$ value $<0.05$ ). 


\section{Identifying Adaptation and Mitigation Strategies}

In line with the characterization of the climate vulnerability of the regions and in accord with widely validated criteria of the regions [21]-[27] we recommend as potential adaptation practices: 1) the use of improved genotypes, whereas the mitigation strategies might include, 2) the use of polycultures systems (e.g. consortium, agroforestry and afforestation), 3) higher density of planting, 4) the use of irrigation systems (e.g. supplementary or total mode) and the 5) management of spontaneous plants, which will be detailed below.

\section{Genetic Improvement}

The most adequate strategy of climate vulnerability adaptation is the breed of genetically improved genotypes with tolerance traits to the environmental constraints, namely, to low water availability and stressing temperatures, which is recommended for all regions (North, Northeast, Central and South). As a result of genetic improvement programs, there are clonal groups with appreciable tolerance to the water deficit, with emphasis to Emcapa 8141 (group of 10 clones), Incaper 8142 (group of 13 clones), Incaper 8112 (group of nine clones), Incaper 8122 (group of nine clones) and Incaper 8132 (group of nine clones) that presented average productivities of $3.24,4.22,4.84,5.33,4.94$ ton/ha, respectively [34]-[39].

Still much remains to be done in Robusta improvement to drought tolerance since its clones usually present high genetic variability in the morpho-physiological impact and in tolerance [40]. Besides this, rainfall seasonability (Figure 8) in the months of greater index of rainfall (November to January) constitutes a further negative factor due to the influence of the polygenic influence nature of tolerance among the clones [35] [41].

There are evidences that some clones have the ability to maintain cellular hydration when exposed to water deficit conditions [2] [42], what was related to an efficient control mechanism of stomata closure. Also, it was reported that the main components of different adaptation relative to the water deficit among coffee clones related to the water use and/or for the efficiency of water extraction from the soil [42]. In fact, the better breeding/screening strategy should consider plants with an efficient radicular system, satisfactory stomata sensitivity and high hydraulic conductance. These clones will have a balance between the capacity of minimizing water loss due to transpiration loss and the efficiency in water absorption, which allows for reasonable stomata opening, for the $\mathrm{CO}_{2}$ influx. These are called double aptitude clones due to the characteristic of tolerance and responsiveness soil water [1] [7] [43].

\section{Conclusions}

The results show that the vulnerability of Robusta coffee is related to the low index of rainfall, the rainfall seasonability and the water deficiency. In the studied region, there is approximately $42 \%$ of some type of water vulnerability during 
the year, with a severe to medium scale; this vulnerability is very pronounced in regions farther away from the coast of the Atlantic Ocean, since for a year approximately $92 \%$ of them are water deficient. In addition, the data show that this distance from the ocean implies a reduction of $75 \%$ in the phases of water surplus not only. For an effective adaptation it was suggested the planting of selected/improved coffee genotypes obtained from large plant screening and genetic improvement programs. As mitigation important components of an effective strategy it should be considered the used of agroforestry consortia, the increase in plant density, the implementation of irrigation and the management of spontaneous plants.

\section{Acknowledgements}

The authors thank the researcher Leandro Roberto Feitoza and Incaper/Geobases for supplying the climate data used in this paper. This work was supported by the Universidade Federal do Espírito Santo, by the Portuguese national funds through Fundação para a Ciência e Tecnologia, under the scope of the project PTDC/AGR-PRO/3386/2012 (JCR), as well through the grants from CNPq (LDM, ARS and MAT), CAPES (LDM in PDSE/12226/12-2) and FAPES (FCE, WNR and LDM-under the scope of the project FAPES/CNPq No. 012/2014-DCR-No. 71444289/15).

\section{Conflicts of Interest}

The authors declare no conflicts of interest regarding the publication of this paper.

\section{References}

[1] ICO (International Coffee Organization) (2018) Trade statistics. http://www.ico.org/trade_statistics.asp

[2] DaMatta, F.M., Avila, R., Cardoso, A., Martins, S. and Ramalho, J.C. (2018) Physiological and Agronomic Performance of the Coffee Crop in the Context of Climate Change and Global Warming: A Review. Journal of Agricultural and Food Chemistry, 66, 5264-5274. https://doi.org/10.1021/acs.jafc.7b04537

[3] Martins, L.D., Eugenio, F.C., Rodrigues, W.N., Tomaz, M.A., Santos, A.R. and Ramalho, J. (2018) Carbon and Water Footprints in Brazilian Coffee Plantations-The Spatial and Temporal Distribution. Emirates Journal of Food and Agriculture, 30, 482-487.

[4] Martins, M.Q., Fortunato, A.S., Rodrigues, W.P., Partelli, F.L., Campostrini, E., Lidon, F.C., DaMatta, F.M., Ramalho, J.C. and Ribeiro-Barros, A.I. (2017) Selection and Validation of Reference Genes for Accurate RT-qPCR Data Normalization in Coffea spp. under a Climate Changes Context of Interacting Elevated $\left[\mathrm{CO}_{2}\right]$ and Temperature. Frontiers in Plant Science, 8, 307. https://doi.org/10.3389/fpls.2017.00307

[5] Ghini, R., Torre-Neto, A., Dentzien, A.F.M., Guerreiro-Filho, O., Iost, R., Patrício, F.A., Prado, J.S.M., Thomaziello, R.A., Bettiol, W. and DaMatta, F.M. (2015) Coffee Growth, Pest and Yield Responses to Free-Air $\mathrm{CO}_{2}$ Enrichment. Climatic Change, 
32, 307-320. https://doi.org/10.1007/s10584-015-1422-2

[6] DaMatta, F.M., Godoy, A.G., Menezes-Silva, P.E., Martins, S.C.V., Sanglard, L.M.V.P., Morais, L.E., Torre-Neto, A. and Ghini, R. (2016) Sustained Enhancement of Photosynthesis in Coffee Trees Grown under Free-Air $\mathrm{CO}_{2}$ Enrichment Conditions: Disentangling the Contributions of Stomatal, Mesophyll, and Biochemical Limitations. Journal of Experimental Botany, 167, 341-352.

https://doi.org/10.1093/jxb/erv463

[7] Martins, L.D., Tomaz, M.A., Lidon, F.C., DaMatta, F.M. and Ramalho, J.C. (2014) Combined Effects of Elevated $\left[\mathrm{CO}_{2}\right]$ and High Temperature on Leaf Mineral Balance in Coffea spp. Plants. Climatic Change, 126, 365-379.

https://doi.org/10.1007/s10584-014-1236-7

[8] Ramalho, J.C., DaMatta, F.M., Rodrigues, A.P., Scotti-Campos, P., Pais, I., Batista-Santos, P., Partelli, F.L., Ribeiro, A., Lidon, F.C. and Leitão, A.E. (2014) Cold Impact and Acclimation Response of Coffea spp. Plants. Theoretical and Experimental Plant Physiology, 26, 5-18. https://doi.org/10.1007/s40626-014-0001-7

[9] Ramalho, J.C., Rodrigues, A.P., Semedo, J.N., Pais, I.P., Martins, L.D., Simões-Costa, S.C., Leitão, A.E., Fortunato, A.S., Batista-Santos, P., Palos, I.M., Tomaz, M.A., Scotti-Campos, P., Lidon, F.C. and DaMatta, F.M. (2013) Sustained Photosynthetic Performance of Coffea spp. under Long-Term Enhanced $\left[\mathrm{CO}_{2}\right]$. PLoS ONE, 8, e82712. https://doi.org/10.1371/journal.pone.0082712

[10] Menezes-Silva, P.E., Sanglard, L.M.V.P., Ávila, R.T., Morais, L.E., Martins, S.C.V., Nobres, P., Patreze, C.M., Ferreira, M.A., Araújo, W.L., Fernie, A.R. and DaMatta, F.M. (2017) Photosynthetic and Metabolic Acclimation to Repeated Drought Events Play Key Roles in Drought Tolerance in Coffee. Journalof Experimental Botany, 68, 4309-4322. https://doi.org/10.1093/jxb/erx211

[11] Guedes, F.A., Nobres, P., Rodrigues, D.C.F., Menezes-Silva, P.E., Ribeiro-Alves, M., Correa, R.L., DaMatta, F.M. and Alves-Ferreira, M. (2018) Transcriptional Memory Contributes to Drought Tolerance in Coffee (Coffea canephora) Plants. Environmental and Experimental Botany, 147, 220-233.

https://doi.org/10.1016/j.envexpbot.2017.12.004

[12] Ferrão, R.G., Ferrao, M.A.G., Fonseca, A.F.A., Ferrao, L.F.V. and Pacova, B.E.V. (2017) Melhoramento genético de Coffeacanephora. In: Ferrão, R.G., Fonseca, A.F.A., Ferrao, M.A.G. and Muner, L.H., Org., Cafeconilon, 2nd Edition, Incaper, Vitoria ES, 2, 131-168.

https://www.embrapa.br/busca-de-publicacoes/-/publicacao/908797/melhoramento -genetico-de-coffea-canephora-no-estado-do-espirito-santo

[13] Nascimento, F.H., Saraiva, A.L.B.C., Coelho, A.LN. and Correa, W.S.C. (2012) Espacialização e análise das temperaturas e precipitações médias anuais do Espírito Santo com o uso de geotecnologias. Revista Geonorte, 2, 1328-1338.

[14] IBGE (Instituto Brasileiro de Geografia e Estatística) (2013) Perfil dos Municípios Brasileiros-2013.

http://www.ibge.gov.br/home/estatistica/economia/perfilmunic/2012

[15] Miranda, E.E. (2015) Brasil em Relevo. (Embrapa Monitoramento por Satélite). http://www.relevobr.cnpm.embrapa.br

[16] Pirovani, D.B. (2014) Cenários de mudanças climáticas e impacto no zoneamento agroclimático de espécies florestais no estado do Espírito Santo. Tese (doutorado em Produção Vegetal), Universidade Federal do Espírito Santo, Centro de Ciências Agrárias, Alegre-ES, 133.

[17] Pirovani, D.B., Pezzopane, J.E.M., Xavier, A.C., Pezzopane, J.R.M., Jesus Jr., W.C., 
Machuca, M.A.H., Santos, G.M.A.D.A., Silva, S.F., Almeida, S.L.H., Peluzio, T.M.O., Eugenio, F.C., Moreira, T.R., Alexandre, R.S. and Santos, A.R. (2018) Climate Change Impacts on the Aptitude Area of Forest Species. Ecological Indicators, 95, 405-416. https://doi.org/10.1016/j.ecolind.2018.08.002

[18] Thornthwaite, C.W. and Mather, J.R. (1955) The Water Balance. Publications in Climatology, Drexel Inst. of Technology, 104.

[19] Ferrant, S., Caballero, Y., Perrin, J., Gascoin, S., Dewandel, B., Aulong, S., Dazin, F., Shakeel, A.S. and Marechal, J.C. (2014) Projected Impacts of Climate Change on Farmers Extraction of Groundwater from Crystalline Aquifers in South India. Scientific Reports, 4, Article No. 3697.

[20] Castro, F.S., Pezzopane, J.E.M., Cecílio, R.A., Pezzopane, J.R.M. and Xavier, A.C. (2010) Avaliação do desempenho dos diferentes métodos de interpoladores para parâmetros do balanço hídrico climatológico. Revista Brasileira de Engenharia Agrícola e Ambiental, 14, 871-880. https://doi.org/10.1590/S1415-43662010000800012

[21] Schroth, G., Laderach, P., Dempewolf, J., Philpott, S., Haggar, J., Eakin, H. and Ramirez-Villegas, J. (2009) Towards a Climate Change Adaptation Strategy for Coffee Communities and Ecosystems in the Sierra Madre de Chiapas, Mexico. Mitigation and Adaptation Strategies for Global Change, 14, 605-625. https://doi.org/10.1007/s11027-009-9186-5

[22] Camargo, M.B.P. (2010) The Impact of Climatic Variability and Climate Change on Arabic Coffee Crop in Brazil. Bragantia, 69, 239-247. https://doi.org/10.1590/S0006-87052010000100030

[23] Läderach, P., Haggar, J., Lau, C., Eitzinger, A., Ovalle, O., Baca, M., Jarvis, A. and Lundy, M. (2010) Mesoamerican Coffee: Building a Climate Change Adaptation Strategy. CIAT Policy Brief n. 2, CIAT, Cali, 4.

https://ccafs.cgiar.org/publications/mesoamerican-coffee-building-climate-changeadaptation-strategy\#.W5FAAugzrIU

[24] Lin, B.B. (2010) The Role of Agroforestry in Reducing Water Loss through Soil Evaporation and Crop Transpiration in Coffee Agroecosystems. Agricultural and Forest Meteorology, 150, 510-518. https://doi.org/10.1016/j.agrformet.2009.11.010

[25] Haggar, J. and Schepp, K. (2012) Coffee and Climate Change: Impacts and Options for Adaptation in Brazil, Guatemala, Tanzania and Vietnam. Climate Change, Agriculture and Natural Resources Working Paper Series No. 4, Natural Resources Institute, University of Greenwich, London, 12.

http://www.academia.edu/2050482/Coffee_and_Climate_Change_Impacts_and_Op tions_for_Adaptation_in_Brazil_Guatemala_Tanzania_and_Vietnam

[26] Rahn, E., Läderach, P., Baca, M., Cressy, C., Schroth, G., Malin, D. and Shriver, J. (2014) Climate Change Adaptation, Mitigation and Livelihood Benefits in Coffee Production: Where Are the Synergies? Mitigation and Adaptation Strategies for Global Change, 19, 1119-1137. https://doi.org/10.1007/s11027-013-9467-x

[27] Eakin, H., Tucker, C.M., Castellanos, E., Diaz-Porras, R., Barrera, J.F. and Morales, H. (2014) Adaptation in a Multi-Stressor Environment: Perceptions and Responses to Climatic and Economic Risks by Coffee Growers in Mesoamerica. Environment, Development and Sustainability, 16, 123-139. https://doi.org/10.1007/s10668-013-9466-9

[28] Cruz, C.D. (2013) GENES—Software Package for Analysis in Experimental Statistics and Quantitative Genetics. Acta Scientiarum Agronomy, 35, 271-276. https://doi.org/10.4025/actasciagron.v35i3.21251 
[29] Bertoni, J.C. and Tucci, C.E.M. (2002) Precipitação. In: Tucci, C.E.M., Ed., Hidrologia: Ciência e aplicação, No. 3, UFRGS/ABRH, Porto Alegre, 77-231.

[30] Antongiovanni, L.L. and Coelho, A.L.N. (2005) Panorama sobre desertificação no Estado do Espírito Santo, 90.

http://plataforma.redesan.ufrgs.br/biblioteca/pdf_bib.php?COD_ARQUIVO=16820

[31] Matiello, J.B. (1991) O café: Do cultivo ao consumo. Globo, São Paulo, 319.

[32] Cecílio, R.A., Silva, K.R., Xavier, A.C. and Pezzopane, J.R.M. (2012) Método para a espacialização dos elementos do balanço hídrico climatológico. Pesquisa Agropecuária Brasileira, 47, 478-488. https://doi.org/10.1590/S0100-204X2012000400002

[33] Martins, L.D. (2015) Implicações das alterações ambientais em Coffeaspp. Tese (doutorado em Produção Vegetal), Universidade Federal do Espírito Santo, Centro de Ciências Agrárias, Alegre-ES, 133.

[34] Ferrão, R.G., Fonseca, A.F.A., Ferrao, M.A.G. and Santos, L.P. (2000) Comportamento de clones elites de café conilon em condições de alta tecnologia no estado do Espírito Santo. In: I Simpósio de Pesquisa dos cafés do Brasil, No. 1, Embrapa Café e Minasplan, Poços de Caldas-MG, 769-771.

https://biblioteca.incaper.es.gov.br/busca?b=pc\&id=7402\&biblioteca=vazio\&busca= assunto:Caf\%C3\%A9\&qFacets=assunto:Caf\%C3\%A9\&sort=\&paginacao=t\&pagina $\underline{\text { Atual }=20}$

[35] Ferrão, R.G., Cruz, C.D., Ferreira, A., Cecon, P.R., Ferrão, M.A.G., Fonseca, A.F.A., Carneiro, P.C.S. and Silva, M.F. (2008) Parâmetros genéticos em café Conilon. Pesquisa Agropecuária Brasileira, 43, 61-69. https://doi.org/10.1590/S0100-204X2008000100009

[36] Ferrão, M.A.G., Ferrão, R.G., Fonseca, A.F.A., Verdim Filho. A.C., Volpi, P.S., Souza, E.M.R. and Moreli, A.P. (2011) Cultivares de café arabica e conilon recomendadas para o estado do espírito santo. In: Tomaz, M.A., Amaral, J.F.T., Jesus Junior, W.C., Fonseca, A.F.A., Ferrão, R.G. and Ferrão, M.A.G., Eds., Tecnologia para Sustentabilidade da Cafeicultura, No. 3 UFES, Centro de Ciências Agrárias, Alegre, 51-68. https://phytotechnics.com/content/files/livro03-01.pdf

[37] Ferrão, R.G., Ferrao, M.A.G., Fonseca, A.F.A., Volpi, P.S., Verdim Filho, A.C., Lani, J.A. and Mauri, A.L. (2013) Diamante Incaper 8112: Nova variedade de café conilon de maturação precoce para o Espírito Santo, Documento No. 219 (DCM/Incaper, Vitoria-ES), 01-05. https://biblioteca.incaper.es.gov.br/digital/handle/item/29

[38] Ferrão, R.G., Ferrao, M.A.G., Fonseca, A.F.A., Volpi, P.S., Verdim Filho, A.C., Lani, J.A. and Mauri, A.L. (2013b) Jequitibá Incaper 8122: Nova variedade de café conilon de maturação intermediária para o Espírito Santo. Documento No. 220 (DCM/Incaper, Vitoria-ES), 01-05.

https://bibliotecaruitendinha.incaper.es.gov.br/Contents/Item/Display/591

[39] Ferrão, R.G., Ferrao, M.A.G., Fonseca, A.F.A., Volpi, P.S., Verdim Filho, A.C., Lani, J.A. and Mauri, A.L. (2013c) Centenária Incaper 8132: Nova variedade de café conilon de maturação tardia para o Espírito Santo. Documento No. 221 (DCM/Incaper, Vitória-ES), 01-05.

https://bibliotecaruitendinha.incaper.es.gov.br/Contents/Item/Display/593

[40] DaMatta, F.M. and Ramalho, J.D.C. (2006) Impacts of Drought and Temperature Stress on Coffee Physiology and Production: A Review. Brazilian Journal of Plant Physiology, 18, 55-81. https://doi.org/10.1590/S1677-04202006000100006

[41] DaMatta, F.M. (2004) Ecophysiological Constraints on the Production of Shaded and Unshaded Coffee: A Review. Field Crops Research, 86, 99-114. https://doi.org/10.1016/j.fcr.2003.09.001 
[42] Cavatte, P.C., Oliveira, A.A.G., Martins, S.V., Wolfgramm, R. and DaMatta, F.M. (2008) Desenvolvimento de variedades visando à tolerância à seca em Coffeacanephora: Um enfoque fisiológico. In: Tomaz, M.A., Amaral, J.F.T., Jesus Junior, W.C., Fonseca, A.F.A., Ferrão, R.G., Ferrão, M.A.G. and Pezzopane, J.R.M., Eds., Seminário para a Sustentabilidade da Cafeicultura, No. 1, UFES, Centro de Ciências Agrárias, Alegre-ES, 01-20.

https://phytotechnics.com/content/files/livro03-01.pdf

[43] Ronchi, C.P. and DaMatta, F.M. (2007) Aspectos fisiológicos do café conilon. In: Ferrão, R.G., Fonseca, A.F.A., Bragança, S.M., Ferrão, M.A.G. and DeMuner, L.H., Eds., O Café Conilon, Incaper, Vitória-ES, 95-115. 